Article

\title{
Correlation between Cyclosporine Blood Levels and Area under Blood Concentration Time Curve in Iraqi Bone Marrow Transplant Patients Treated with Neoral ${ }^{\circledR}$ Oral Solution
}

\author{
Hassan M. Abass ${ }^{1}$, Kawther F. Al-Tamimi ${ }^{2}$, Duaa J. Al-Tamimi ${ }^{3}$ and Jaafar J. Ibraheem ${ }^{4, *}$ \\ 1 Baghdad Teaching Hospital, Medical City, Ministry of Health, Baghdad 10069, Iraq; Drhaltemimi@dr.com \\ 2 TDM Center, Baghdad Teaching Hospital, Medical City, Ministry of Health, Baghdad 10069, Iraq; \\ kawther.kf@gmail.com \\ 3 Department of Pharmacy, Al-Rasheed University College, Ministry of Higher Education and Scientific \\ Research, Baghdad 10069, Iraq; duaa.jaafaraltamimi@yahoo.com \\ 4 Pharmacy College, Al-Farahidi University, Ministry of Higher Education and Scientific Research, \\ Baghdad 10069, Iraq \\ * Correspondence: drjaafarjaber@yahoo.com
}

Received: 27 January 2020; Accepted: 5 March 2020; Published: 11 March 2020

\begin{abstract}
Cyclosporine is a potent immunosuppressive drug. It has a narrow therapeutic index, and therefore the measurement of cyclosporine's blood concentration is essential to obtain optimal therapy. Measurement of the area under the blood concentration-time curve (AUC) is reflective of total drug exposure. However, for organ transplant patients, the measurement of AUC involves many problems and difficulties. Thus, it is more clinically acceptable to use a single blood sample as a surrogate index of total drug exposure. Fifty-four adults bone marrow transplant Iraqi patients were given cyclosporine every $12 \mathrm{~h}$ as prophylaxis using Neoral ${ }^{\circledR}$ oral solution. Steady-state blood concentrations were monitored for each patient at zero time and then at 1, 2, 3, 4, 6, 8, 10, and at $12 \mathrm{~h}$ post-dosing. Cyclosporine blood levels were determined by using AXSYM automated immuno-analyzer which is a fluorescence polarization immunoassay (FPIA). The present investigation demonstrated the best correlation between $\mathrm{C} 2$ and the corresponding $\mathrm{AUC}_{0-4 \mathrm{~h}}$ and $\mathrm{AUC}_{0-12 \mathrm{~h}}$ compared to other concentrations. After two months of cyclosporine therapy, no unexpected biochemical changes and adverse effects were registered. It is concluded from this study that a single blood sample obtained at $2 \mathrm{~h}$ post-dosing (C2) and possibly at $3 \mathrm{~h}$ post dosing (C3) are ideal surrogate indexes for reflecting total drug exposure, and therefore may be used in clinical practice for predicting therapeutic and toxic effects of cyclosporine.
\end{abstract}

Keywords: bone marrow transplant Iraqi patients; cyclosporine blood concentrations; AUC; biochemical changes; adverse effects

\section{Introduction}

Cyclosporine (also called cyclosporin A) is a cyclic polypeptide, potent immunosuppressive agent (a calcineurin inhibitor) consisting of 11 amino acids with a molecular weight of 1202.63. It is produced as a metabolite by the fungus species Beauveria Nivea. Cyclosporine is available as soft gelatin capsule in 10, 25, 50, and $100 \mathrm{mg}$ dose strengths, and as oral solution containing $100 \mathrm{mg} / \mathrm{mL}$ of cyclosporine. The drug is extensively metabolized in the liver and about $90 \%$ protein bound. Its disposition shows biphasic decay from blood with a terminal half-life of about $8.4 \mathrm{~h}$ (range 5-18 h) after intravenous administration. Its elimination is mainly biliary with only around $6 \%$ urinary excretion as parent drug 
and metabolites. Cyclosporine achieves maximum concentration in plasma within 1.5-2.0 h. There is a linear relationship between the administered therapeutic dose range of cyclosporine and the total drug exposure [1].

The early impressive and promising results for using cyclosporine in kidney transplantation led to the subsequent usage of the drug in other organ transplant patients and for the treatment of many and different autoimmune diseases [2].

The pharmacokinetics of cyclosporine is highly complex and has many and different influential factors [3]. Among these factors are the high inter- and intra-individual variability in disposition, type and time of organ transplantation, demographic factors, concomitant therapy (drug interactions), physiological and biochemical factors [4,5]. Moreover, administration of cyclosporine orally adds further pharmacokinetic problems in comparison to the intravenous route since the absorption is incomplete, variable, and shows high inter- and intrasubject differences [3,6]. Therefore, several pharmacokinetic and clinical factors such as the age, dosage form used, route of administration, food intake, gastrointestinal status, renal dysfunction, and hepatic dysfunction have a significant impact on the rate and extent of cyclosporine absorption and bioavailability. Besides, it has been found that posttransplant day significantly influences cyclosporine pharmacokinetics, and there was a significant reduction in drug clearance until day 21 post-transplantation [7]. Therefore, maintaining a balance between the therapeutic and safe cyclosporine concentrations is challenging since all the above-mentioned factors must be taken into consideration to obtain the optimal effect and minimum adverse effects.

From a pharmacokinetic point of view; the maximum drug concentration in plasma (Cmax) and the total drug exposure which is estimated by measuring the area under the concentration versus time curve (AUC) are reflective of the rate/extent of drug absorption and bioavailability. Therefore, Cmax and AUC are considered as primary pharmacokinetic parameters [8,9]. Besides, the time to peak (Tmax) can also provide valuable information concerning the rate of drug absorption [9,10]. Further, from a pharmacodynamic point of view, Cmax and AUC are the parameters most closely related to the onset, intensity, and duration of clinical effect/side effect of drugs since they reflect the absorption and total exposure [11,12].

The clinical effect of cyclosporine is closely related to its blood concentrations and AUC in both adult and pediatric organ transplant patients. Concerning the correlation between cyclosporine blood concentration and its clinical effect, it was found that the incidence of acute graft-versus-host disease (GVHD) significantly decreased with higher cyclosporine blood levels in the third week post allogeneic hematopoietic stem cell transplantation [13]. Another investigation emphasized the relevance of sustaining adequate cyclosporine blood levels by close monitoring and dose adjustments since it may lead to a reduction in the intensity of GVHD [14]. High blood levels of cyclosporine might account for the impairment of donor T-cell function which justifies the correlation between cyclosporine blood levels and its immunosuppressant effect [15]. Moreover, the strong association found between cyclosporine concentration and its clinical outcome suggests that improved cyclosporine pharmacokinetic monitoring may aid in improving its clinical outcome. In solid organ transplantation,

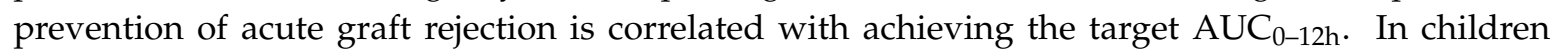
undergoing hematopoietic stem cell transplantation, a limited sampling strategy using $\mathrm{AUC}_{0-12 \mathrm{~h}} \mathrm{was}$ suggested for the prevention of acute GVHD [16]. The relationship between AUC of cyclosporine and the patient's creatinine clearance, hematocrit and other clinical factors were also investigated, and it was observed that hematocrit had a significant negative correlation with AUC, whereas creatinine clearance and obesity had a significant positive correlation with AUC [17].

The most reliable sampling program in cyclosporine therapy after oral administration twice daily for measuring $\mathrm{AUC}_{0-12 \mathrm{~h}}$ is by frequent monitoring of cyclosporine blood concentrations before drug intake (C0), and then after; 1 (C1), 2 (C2), 3 (C3), 4 (C4), 6 (C6), 8 (C8), and after 12 h (C12) of drug administration to identify all the pharmacokinetic profile including drug absorption, distribution and elimination phases [11,12]. At steady state, $\mathrm{C} 0$ is assumed to be equivalent to $\mathrm{C} 12$ and represents the 
trough concentration. However, in clinical practice, it is often difficult to determine $\mathrm{AUC}_{0-12 \mathrm{~h}}$ after drug administration since reliable calculation of AUC by trapezoidal rule requires the collection of several blood samples (at least 8 samples, as mentioned above) which involves many difficulties for organ transplant patients such as withdrawal of large total blood volume which is of special concern in pediatrics, increase patient's distress, high cost and medical staff duties.

Therefore, many ongoing and outstanding investigations were conducted in many places and centers worldwide for different types of organ transplantation and for adults and children to find a valid limited sampling strategy using 3 or 4 blood samples after 1 (C1), 2 (C2), 3 (C3), or 4 (C4) hours of cyclosporine intake that best correlate with AUC in order to evaluate the relationship between cyclosporine concentrations and drug exposure [18].

Therapeutic drug monitoring based on a single data point strategy was also studied to determine the best correlation between cyclosporine levels and AUC $[19,20]$. The measurement of $\mathrm{AUC}_{0-4 \mathrm{~h}}$ was suggested as an alternative approach to $\mathrm{AUC}_{0-12 \mathrm{~h}}$ and a good correlation was found between $\mathrm{AUC}_{0-4 \mathrm{~h}}$ and the clinical outcome for heart transplant recipients [21], lung transplant patients [22], and other organ allografts, particularly kidney and liver transplantation, indicating the use of $\mathrm{AUC}_{0-4 \mathrm{~h}}$ as a surrogate index for reflecting cyclosporine absorption and exposure [23]. Nevertheless, $\mathrm{AUC}_{0-4 \mathrm{~h}}$ measurement still poses many difficulties and burdens for organ transplant recipients as $\mathrm{AUC}_{0-12 \mathrm{~h}}$ but to a lower extent since a lower number of blood samples are required to be withdrawn from the patients.

Interestingly, several articles demonstrated the best correlation between $\mathrm{C} 2$ and $\mathrm{AUC}_{0-4 \mathrm{~h}}$ in different nations and for different types of organs allograft. Among these studies, were reported for lung transplantation [22], liver transplant recipients [24], heart transplantation [21,25], allogeneic stem cell transplantation [26], for children with idiopathic nephrotic syndrome [27], and for other types of organs transplantations $[23,28]$. The best correlation was also found between cyclosporine $\mathrm{C} 2$ level and AUC0-6hr for patients with corticosteroid resistant systemic lupus erythematosus [29].

Moreover, other investigations demonstrated the greatest correlation between C2, C3 and C4 cyclosporine levels and their corresponding $\mathrm{AUC}_{0-12 \mathrm{~h}}$. Among these studies which were conducted for allogeneic hematopoietic stem cell transplantation [30], allogeneic stem cell transplantation [31,32], renal transplant patients [19], for HIV infected kidney and liver transplant patients [20], for pediatric hematopoietic stem cell transplant [33], for children with idiopathic nephrotic syndrome [27], and for pediatric stem cell recipients [34].

On the other hand, it appeared in most of the above-mentioned investigations $[20,22,24,25,29,30,34]$ that cyclosporine trough level at (C0) exhibited a poor correlation with total drug exposure $\left(\mathrm{AUC}_{0-4 \mathrm{~h}}\right.$ and $\mathrm{AUC}_{0-12 \mathrm{~h}}$ ). Furthermore, many clinical trials demonstrated that $\mathrm{C} 2$ is a better predictor than $\mathrm{C} 0$ and consequently may be used as an appropriate tool to monitor cyclosporine effect and safety profile [35-37]. Therefore, cyclosporine dose adjustment based on monitoring of a single steady-state blood concentration at $(\mathrm{C} 2)$ rather than $\mathrm{AUC}_{0-4 \mathrm{~h}}$ or $\mathrm{AUC}_{0-12 \mathrm{~h}}$ became the standard of care in cyclosporine therapy with international consensus [38].

Therapeutic drug monitoring (TDM) services started about 10 years ago in TDM center, Baghdad Teaching Hospital, Medical City, Baghdad, Iraq. However, there are no published data concerning the utilization of TDM for optimal dosing of cyclosporine in Iraqi bone marrow transplantation. Besides, no study was done up to date to prove that the use of $\mathrm{C} 2$ as a single sampling time is valid for Iraqi patients to facilitate its use in clinical practice. Therefore, the present investigation aimed to study the clinical pharmacokinetics of cyclosporine as an immunosuppressant drug for prophylaxis of GVHD in Iraqi bone marrow transplant patients who are using cyclosporine for the first time. Cyclosporine blood levels were determined by using AXSYM automated immuno-analyzer which is a fluorescence polarization immunoassay (FPIA). The correlations between each of $\mathrm{C} 0, \mathrm{C} 1, \mathrm{C} 2, \mathrm{C} 3, \mathrm{C} 4$, $\mathrm{C} 6, \mathrm{C} 8, \mathrm{C} 10$, and $\mathrm{C} 12$ of cyclosporine and their corresponding pharmacokinetic parameters $\mathrm{AUC}_{0-4 \mathrm{~h}}$ and $\mathrm{AUC}_{0-12 \mathrm{~h}}$ were evaluated to identify the blood concentration which best correlates with these 
parameters. The biochemical changes and adverse effects associated with cyclosporine therapy were also recorded.

\section{Materials and Methods}

\subsection{Study Design}

The current investigation was conducted adhering with ICH guidelines for good clinical practice [39] and the recent version of the declaration of Helsinki [40]. The site of the study was TDM center, Baghdad Teaching Hospital, Medical City, Baghdad, Iraq. Before commencement of the investigation, approval was obtained from the ethical committee of Baghdad Teaching Hospital, Medical City, Ministry of Health, Baghdad, Iraq. All the patients gave written and signed informed consents before participation in the study. The study involved the participation of 54 Iraqi adult inpatients who underwent bone marrow transplantation, 34 females and 20 males with ages ranging from $18-56$ years.

Three ml blood sample was collected from each patient to be used for clinical laboratory tests before cyclosporine administration (baseline) and then after 2 months of continuous drug intake. These tests were; triglyceride (TG), total cholesterol (TC), aspartate transaminase (AST), alanine transaminase (ALT), bilirubin, serum creatinine, blood urea, uric acid, potassium (K), and magnesium (Mg). Systolic and diastolic blood pressure were also measured for each patient before drug intake (baseline) and then after two months of continuous drug administration. The patients were given Neoral ${ }^{\circledR}(\mathrm{NEO}$, Novartis) oral solution containing $100 \mathrm{mg}$ of cyclosporine $/ \mathrm{mL}$ twice daily in a dose of $3 \mathrm{mg} / \mathrm{kg} /$ day according to the in-house protocol applied in the TDM center of Baghdad Teaching Hospital in Iraq. Concurrent food intake during cyclosporine therapy was carefully controlled by giving each patient a list of the types of food which are safe and can be taken and those which are unsafe and should be avoided as described in Figure 1. Biochemical changes and observed adverse effects associated with cyclosporine therapy were registered for each patient during the study.

The patients with the following characteristics were not included in the study: developing GVHD, receiving another drug which may interfere with cyclosporine, showing evidence of uncontrolled digestive problems, having renal dysfunction (more than double normal creatinine level), or hepatic dysfunction (more than double bilirubin and aminotransferases normal levels). 


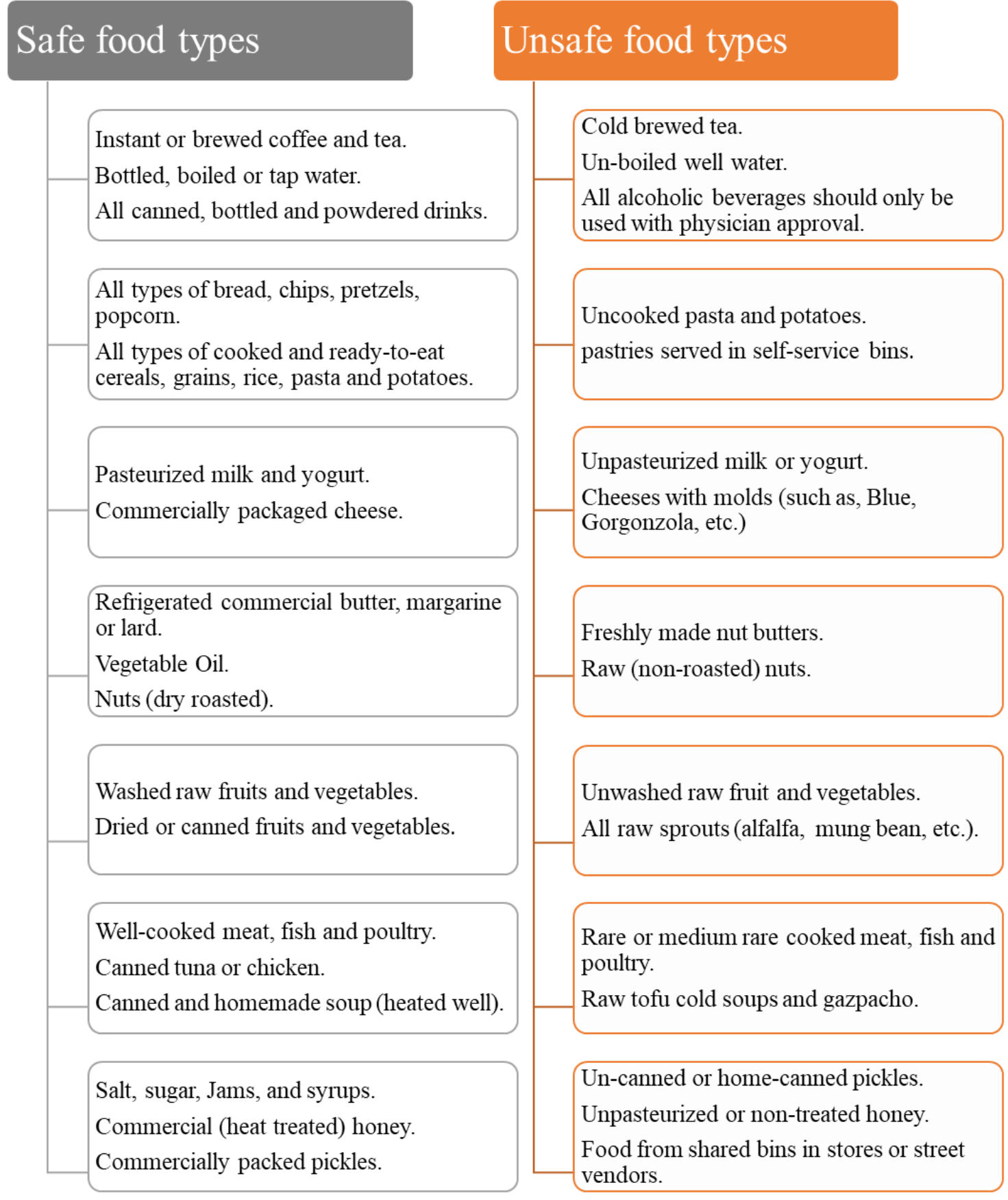

Figure 1. Food types to choose or to avoid for bone marrow transplant patients.

\subsection{Cyclosporine Assay}

Cyclosporine assay was performed in the therapeutic drug monitoring (TDM) center, Baghdad Teaching Hospital, Medical City, Baghdad, Iraq after two months of continuous cyclosporine intake (which is adequate for achieving a steady state of the drug in the body). Three ml blood was sampled from each patient before next drug dosing (about $0.3 \mathrm{~h}$ pre-dosing which is considered as $\mathrm{C} 0$ ), and then at 1(C1), 2(C2), 3(C3), 4(C4), 6(C6), 8(C8), and at $12 \mathrm{~h}$ (C12) post-dosing. The blood was immediately transferred into tubes containing EDTA anticoagulant and then analyzed for determination of cyclosporine blood concentrations by using AXSYM automated immuno-analyzer which is a fluorescence polarization immunoassay (FPIA). 
The equipment and their suppliers were as follows: AXSYM automated immune analyzer from Abbot, centrifuge from Kokusan, vortex from Hitachi, centrifuge tube from Shanghai Zadn, disposable test tube from Shanghai Zadn, different grades of automatic pipettes from Eppendorf, electronic balance scale from Seca Scale. The chemicals used and their suppliers were as follows: AXSYM cyclosporine kit from Abbot, total cholesterol kit from BioMérieux, triglycerides kit from BioMérieux, HDL-c kit from BioMérieux, ALT reagent kit from Randox Lab. Ltd., AST reagent kit from Randox Lab. Ltd., ALT reagent kit from Randox Lab. Ltd., bilirubin kit from Randox Lab. Ltd., urea kit from Biomaghrib/Tunisia, creatinine kit from Randox Lab. Ltd., and K, Na, Ca kits from Biomerieux.

\subsection{Pharmacokinetic and Statistical Analysis}

Standard methods were used for all pharmacokinetic calculations [11,12]. For each patient, $\mathrm{AUC}_{0-4 \mathrm{~h}}$ and $\mathrm{AUC}_{0-12 \mathrm{~h}}$ were calculated using the trapezoidal rule, whereas, $\mathrm{Cmax}$ and Tmax were estimated directly from cyclosporine blood concentration versus time curve. Mean $\pm \mathrm{SD}$, minimum and maximum values of $\mathrm{AUC}_{0-4 \mathrm{~h}}, \mathrm{AUC}_{0-12 \mathrm{~h}}$, and cyclosporine blood concentrations at each blood sampling time point were presented. Regression analysis was carried out between each blood sampling point $\mathrm{C} 0, \mathrm{C} 1, \mathrm{C} 2, \mathrm{C} 3, \mathrm{C} 4, \mathrm{C} 6, \mathrm{C} 8$, and $\mathrm{C} 12$ of each individual and their corresponding $\mathrm{AUC}_{0-4 \mathrm{~h}}$ and $\mathrm{AUC}_{0-12 \mathrm{~h}}$ to calculate the correlation coefficient $\left(\mathrm{R}^{2}\right)$ at each blood sampling point. The difference between data was considered significant if $(p<0.05)$ using t-test. Excel 2010 was used for all statistical data analysis.

\section{Results and Discussion}

The patients' demographical data and the clinical baseline characteristics before starting therapy with cyclosporine are listed in Table 1 . The mean steady-state cyclosporine trough concentrations (C0 and C12) were similar (C0 was $145 \mathrm{ng} / \mathrm{mL}$, and C12 $144.0 \mathrm{ng} / \mathrm{mL}$ ). The average steady-state peak levels (Cmax or Cpeak) was found to be $824.4 \mathrm{ng} / \mathrm{mL}$ (range 700-952) and the corresponding time to peak (Tmax) was $2 \mathrm{~h}$. All patients exhibited similar Tmax values (Table 2). The Mean \pm SD for cyclosporine blood concentration versus time profile is presented in Figure 2.

Table 1. Baseline clinical characteristics and demographic data of 54 patients participated in the study.

\begin{tabular}{ccc}
\hline Patients Characteristics & Mean \pm SD & Range \\
\hline Gender & 20 males, 34 females & \\
Age (years) & $31.2 \pm 10.3$ & $18-56$ \\
Body weight $(\mathrm{kg})$ & $69.1 \pm 10.2$ & $42-83$ \\
Height $(\mathrm{cm})$ & $164.5 \pm 5.4$ & $150-172$ \\
Body Mass Index $\left(\mathrm{kg} / \mathrm{m}^{2}\right)$ & $25.4 \pm 2.8$ & $18.7-29.8$ \\
Systolic blood pressure $(\mathrm{mm} \mathrm{Hg})$ & $120.3 \pm 1.4$ & $116-124$ \\
Diastolic blood pressure $(\mathrm{mmHg})$ & $80.5 \pm 1.6$ & $76-87$ \\
Serum Aspartate transaminase $(\mathrm{U} / \mathrm{L})$ & $25.4 \pm 7.9$ & $10-40$ \\
Serum Alanine transaminase $(\mathrm{U} / \mathrm{L})$ & $28.0 \pm 10.9$ & $10-50$ \\
Serum bilirubin $(\mathrm{mg} / \mathrm{dL})$ & $0.92 \pm 0.18$ & $0.6-1.2$ \\
Blood K (mEq/L) & $4.1 \pm 0.66$ & $3-5$ \\
Blood Mg $(\mathrm{mg} / \mathrm{dL})$ & $2.1 \pm 0.34$ & $1.6-2.8$ \\
Serum creatinine $(\mathrm{mg} / \mathrm{dL})$ & $1.0 \pm 0.17$ & $0.8-1.3$ \\
Blood urea $(\mathrm{mg} / \mathrm{dL})$ & $28.8 \pm 6.4$ & $20-45$ \\
Blood uric acid $(\mathrm{mg} / \mathrm{dL})$ & $5.1 \pm 0.90$ & $3-7$ \\
Total cholesterol $(\mathrm{mg} / \mathrm{dL})$ & $191.1 \pm 20.6$ & $127-230$ \\
Triglyceride $(\mathrm{mg} / \mathrm{dL})$ & $134.9 \pm 9.3$ & $121-150$ \\
\hline
\end{tabular}


Table 2. Cyclosporine steady-state blood levels $(\mathrm{ng} / \mathrm{mL})$ after two months of twice-daily dosing with $3 \mathrm{mg} / \mathrm{kg} /$ day cyclosporine oral solution $\left(\mathrm{Neoral}^{\circledR}, \mathrm{NEO}\right.$, Novartis).

\begin{tabular}{ccc}
\hline Cyclosporine Concentration & Mean \pm SD & Range \\
\hline C0 (0.3 h pre-dosing) & $145.0 \pm 48.3$ & $030-244$ \\
C1 (1h after dosing) & $273.7 \pm 52.7$ & $100-400$ \\
C2 (2 h after dosing) & $824.4 \pm 48.7$ & $700-952$ \\
C3 (3 h after dosing) & $723.4 \pm 47.6$ & $598-850$ \\
C4 (4 h after dosing) & $390.9 \pm 45.9$ & $286-520$ \\
C6 (6 h after dosing) & $251.9 \pm 41.4$ & $180-380$ \\
C8 (8 h after dosing) & $219.0 \pm 43.4$ & $130-350$ \\
C10 (10 h after dosing) & $158.0 \pm 48.4$ & $052-271$ \\
C12 (12 h after dosing) & $144.0 \pm 50.4$ & $025-199$ \\
\hline
\end{tabular}

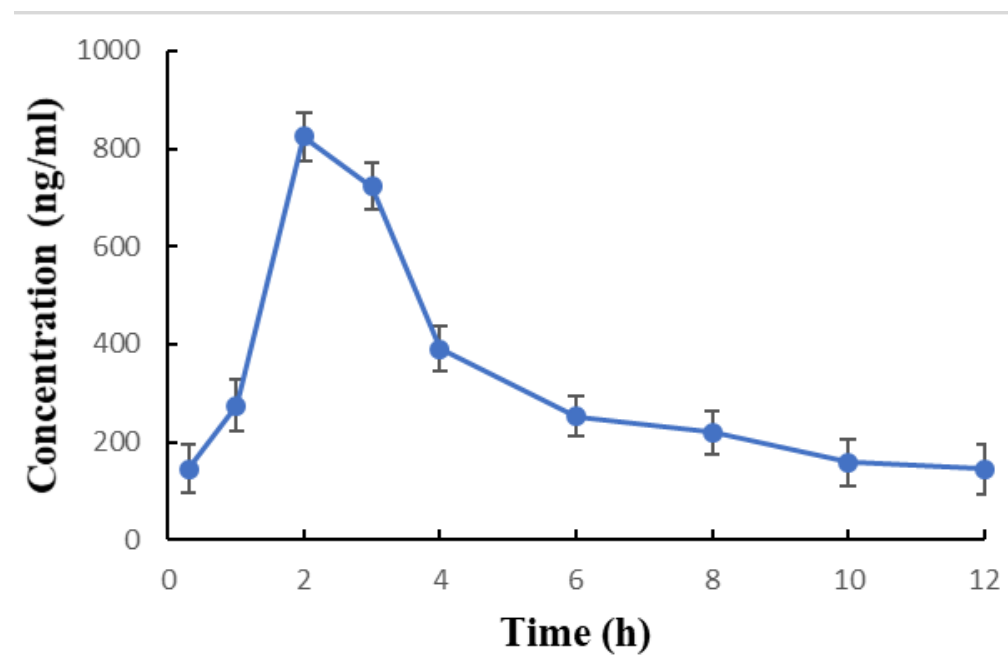

Figure 2. Steady state blood concentrations (Mean $\pm \mathrm{SD}$ ) versus. time profile of cyclosporine after two months of twice daily dosing of $3 \mathrm{mg} / \mathrm{kg} /$ day oral solution (Neoral ${ }^{\circledR}, \mathrm{NEO}$, Novartis).

The Mean \pm SD and the ranges of $\mathrm{AUC}_{0-4 \mathrm{~h}}$ and $\mathrm{AUC}_{0-12 \mathrm{~h}}$ are presented in Table 3. The Mean $\mathrm{AUC}_{0-4 \mathrm{~h}}$ was $2590 \mathrm{ng} \cdot \mathrm{h} / \mathrm{mL}$ (range 1950-3162). The average $\mathrm{AUC}_{0-12 \mathrm{~h}}$ was $3732 \mathrm{ng} \cdot \mathrm{h} / \mathrm{mL}$ (range 2700-5096). The values of the correlation coefficient $\mathrm{R}^{2}$ between each of cyclosporine blood concentrations at $\mathrm{C} 0, \mathrm{C} 1, \mathrm{C} 2, \mathrm{C} 3, \mathrm{C} 4, \mathrm{C} 6, \mathrm{C} 8, \mathrm{C} 10, \mathrm{C} 12$, and the corresponding $\mathrm{AUC}_{0-4 \mathrm{~h}}$ and $\mathrm{AUC}_{0-12 \mathrm{~h}}$ are introduced in Table 4 . Concerning $\mathrm{AUC}_{0-4 h}$, the best correlations were observed at $\mathrm{C} 2\left(\mathrm{R}^{2}=0.94\right)$. $\mathrm{A}$ similar finding was also obtained for $\mathrm{AUC}_{0-12 \mathrm{~h}}\left(\mathrm{R}^{2}=0.90\right)$. On the other extreme, poor correlations were noticed at trough levels (C0 and C12). The correlations coefficient for $A U C_{0-4 h}$ at $C 0$ was $\left(R^{2}=0.43\right)$, and at $C 12\left(R^{2}=0.42\right)$. The correlations coefficient for $A U C_{0-12 h}$ at $C 0\left(R^{2}=0.54\right)$, and at $C 12\left(R^{2}=0.62\right)$ as shown in Table 4.

Table 3. Pharmacokinetic parameters after two months of twice-daily dosing with $3 \mathrm{mg} / \mathrm{kg} / \mathrm{day}$ cyclosporine oral solution (Neoral ${ }^{\circledR}, \mathrm{NEO}$, Novartis).

\begin{tabular}{ccc}
\hline Parameter & Mean $\pm \mathrm{SD}$ & Range \\
\hline $\mathrm{AUC}_{0-12 \mathrm{~h}}(\mathrm{ng} \cdot \mathrm{h} / \mathrm{mL})$ & $3732.5 \pm 451.6$ & $2700.4-5096.0$ \\
$\mathrm{AUC}_{0-4 \mathrm{~h}}(\mathrm{ng} \cdot \mathrm{h} / \mathrm{mL})$ & $2590.1 \pm 225.5$ & $1950.0-3162.0$ \\
$\mathrm{C}_{\max }(\mathrm{ng} / \mathrm{mL})$ & $824.4 \pm 48.7$ & $700.0-952.0$ \\
$\mathrm{C} 0(\mathrm{ng} / \mathrm{mL})$ & $145.0 \pm 48.3$ & $30.0-244.0$ \\
$\mathrm{C} 12(\mathrm{ng} / \mathrm{mL})$ & $144.0 \pm 50.4$ & $25.0-199.0$ \\
$* \mathrm{~T}_{\max }(\mathrm{h})$ & $2.0 *$ & $2.0 *$ \\
\hline
\end{tabular}

* All patients have same $\mathrm{T}_{\max }$. 
Table 4. The correlation coefficient $\left(\mathrm{R}^{2}\right)$ showing the relationship between cyclosporine blood concentrations and their corresponding $\mathrm{AUC}_{0-4 \mathrm{~h}}$ and $\mathrm{AUC}_{0-12 \mathrm{~h} .}$

\begin{tabular}{ccc}
\hline Conc. & $\mathbf{A U C}_{\mathbf{0 - 4 h}}$ & $\mathbf{A U C}_{\mathbf{0 - 1 2 h}}$ \\
\hline $\mathrm{C} 0$ & 0.43 & 0.54 \\
$\mathrm{C} 1$ & 0.85 & 0.86 \\
$\mathrm{C} 2$ & 0.94 & 0.90 \\
$\mathrm{C} 3$ & 0.94 & 0.88 \\
$\mathrm{C} 4$ & 0.93 & 0.86 \\
$\mathrm{C} 6$ & 0.85 & 0.81 \\
$\mathrm{C} 8$ & 0.48 & 0.50 \\
$\mathrm{C} 10$ & 0.49 & 0.68 \\
$\mathrm{C} 12$ & 0.42 & 0.62 \\
\hline
\end{tabular}

For all the 54 patients followed in the current investigation, the results showed that cyclosporine therapy caused significant elevation $(p<0.05)$ in systolic/diastolic blood pressure, TG, TC, AST ALT, bilirubin, creatinine, urea, uric acid, and $\mathrm{K}$ levels from baseline values (before treatment). However, a significant reduction in $\mathrm{Mg}$ level was observed $(-59 \%)$, as shown in Table 5 . The reported adverse effects of the drug and the corresponding number (\%) of the patients for each adverse effect are summarized in Table 6.

Table 5. Biochemical changes observed in 54 adult Iraqi bone marrow transplant patients after two months of twice-daily dosing with $3 \mathrm{mg} / \mathrm{kg} /$ day cyclosporine oral solution (Neoral ${ }^{\circledR}, \mathrm{NEO}$, Novartis). Values are presented as Mean \pm SD.

\begin{tabular}{|c|c|c|c|c|c|c|c|}
\hline Parameter & $\begin{array}{c}\text { Before } \\
\text { Treatment } \\
\text { (baseline) }\end{array}$ & $\begin{array}{c}\text { After } \\
\text { Treatment }\end{array}$ & $\begin{array}{c}\text { Elevation } \\
(\%)\end{array}$ & Parameter & $\begin{array}{c}\text { Before } \\
\text { Treatment } \\
\text { (baseline) }\end{array}$ & $\begin{array}{c}\text { After } \\
\text { Treatment }\end{array}$ & $\begin{array}{c}\text { Elevation } \\
(\%)\end{array}$ \\
\hline SBP $(\mathrm{mm} \mathrm{Hg})$ & $120.3 \pm 1.3$ & $140.3 \pm 1.2$ & 16.6 & Bilirubin (mg/dL) & $0.92 \pm 0.18$ & $1.6 \pm 0.18$ & $73 \%$ \\
\hline $\mathrm{DBP}(\mathrm{mm} \mathrm{Hg})$ & $80.5 \pm 1.7$ & $95.5 \pm 1.1$ & 18.7 & Creatinine $(\mathrm{mg} / \mathrm{dL})$ & $0.96 \pm 0.10$ & $1.6 \pm 0.16$ & $66 \%$ \\
\hline $\mathrm{TC}(\mathrm{mg} / \mathrm{dL})$ & $179 \pm 21.7$ & $254.9 \pm 8.7$ & 42.3 & Urea $(\mathrm{mg} / \mathrm{dL})$ & $34.4 \pm 4.5$ & $50.1 \pm 5.4$ & $45 \%$ \\
\hline $\mathrm{TG}(\mathrm{mg} / \mathrm{dL})$ & $135.4 \pm 9.6$ & $175.6 \pm 9.8$ & 29.7 & Uric acid (mg/dL) & $5.07 \pm 0.95$ & $8.5 \pm 1.18$ & $67 \%$ \\
\hline $\operatorname{AST}(\mathrm{U} / \mathrm{L})$ & $25 \pm 8.1$ & $36 \pm 7.8$ & 44 & $\mathrm{~K}(\mathrm{mEq} / \mathrm{L})$ & $4.1 \pm 0.66$ & $6.4 \pm 0.55$ & $56 \%$ \\
\hline ALT (U/L) & $28 \pm 11$ & $44 \pm 10$ & 57 & $\mathrm{Mg} *(\mathrm{mg} / \mathrm{dL})$ & $2.2 \pm 0.30$ & $0.9 \pm 0.51$ & $59 \% *$ \\
\hline
\end{tabular}

Table 6. Adverse effects of cyclosporine in 54 adult Iraqi bone marrow transplant patients after two months of twice-daily dosing with $3 \mathrm{mg} / \mathrm{kg} /$ day cyclosporine oral solution (Neoral ${ }^{\circledR}, \mathrm{NEO}$, Novartis).

\begin{tabular}{|c|c|c|c|c|c|}
\hline Adverse Effects & $\begin{array}{c}\text { No. of } \\
\text { Patients }\end{array}$ & $\%$ & Adverse Effects & $\begin{array}{c}\text { No. of } \\
\text { Patients }\end{array}$ & $\%$ \\
\hline Nausea, bloating, loose stools, abdominal cramps & 21 & 35 & Tender or swollen gums & 45 & 75 \\
\hline Slight trembling of the hands & 6 & 10 & Acne, oily skin & 14 & 23 \\
\hline Tingling in the fingers, toes, lips & 3 & 5 & Fatigue & 28 & 46 \\
\hline Muscle or joint discomfort, cramping & 9 & 15 & Edema in the legs or ankles & 5 & 8 \\
\hline Sensitivity to heat and cold & 2 & 3 & Mild depression or mood swings & 44 & 73 \\
\hline Mild headaches & 24 & 40 & Increased growth of fine hairs on the body & 33 & 55 \\
\hline
\end{tabular}

The current study was designed to measure cyclosporine blood concentrations at steady state for each patient at $0.3 \mathrm{~h}$ before the next dose administration (which is considered as $\mathrm{C} 0$ ), and then at $1,2,3$, $4,6,8,10$, and $12 \mathrm{~h}$ post-dosing to study the pharmacokinetic behavior of the drug during the entire time course of dosing interval (12 h). In addition, measurements of $\mathrm{AUC}_{0-4 \mathrm{~h}}$ and $\mathrm{AUC}_{0-12 \mathrm{~h}}$ were achieved. Besides, the correlations between each blood concentration measured at the above-mentioned time schedule (Table 2) and their corresponding $\mathrm{AUC}_{0-4 \mathrm{~h}}$ and $\mathrm{AUC}_{0-12 \mathrm{~h}}$ were evaluated to determine the blood sampling time point which is best correlated with $\mathrm{AUC}_{0-4 \mathrm{~h}}$ and $\mathrm{AUC}_{0-12 \mathrm{~h}}$.

It was noticed in this investigation that Tmax values of all patients were comparable and was found to be $2 \mathrm{~h}$ (Table 3). This finding may be due to the blood sampling schedule (Table 2) since according to the purpose and design of this study, blood samples were obtained at 1,2 , and $3 \mathrm{~h}$ 
post-dosing and no blood sample was required to be taken at shorter time interval (i.e., 1.25, 1.50, 1.75, $2.25,2.5$, and 2.75) to notice the difference (if any) between Tmax values of the patients.

It is apparent from Table 4 that best correlations were found between $\mathrm{C} 2$ and possibly $\mathrm{C} 3$ with their corresponding $\mathrm{AUC}_{0-4 \mathrm{~h}}$ and $\mathrm{AUC}_{0-12 \mathrm{~h}}$ compared to other concentrations particularly trough concentrations ( $\mathrm{C} 0$ and $\mathrm{C} 12)$. Therefore, $\mathrm{C} 2$ represents the optimal sampling time point which reflects the total systemic exposure (AUC) and consequently the optimal effect and adverse effect of the drug. Interestingly, the best correlations between $\mathrm{C} 2$ with $\mathrm{AUC}_{0-12 \mathrm{~h}}$ and $\mathrm{C} 2$ with $\mathrm{AUC}_{0-4 \mathrm{~h}}$, in addition to the poor correlation of both AUCs with $\mathrm{C} 0$ found in the current investigation for bone marrow transplant Iraqi patients (Table 4) are similar to the results obtained in studies conducted in other nations and for different types of organ transplantation [19-34].

Measuring blood levels, AUC, and identifying the best correlation between the individual blood level and AUC may not be the optimal way of assessing the biological effect (effect and adverse effect) of cyclosporine. Significant inter-patient differences in the degree of calcineurin inhibition produced by cyclosporine emphasized the significance of correlating biological measures of calcineurin inhibition with clinical outcome. Pharmacodynamic monitoring of the relative reduction of T-cell-specific gene expression, may be a more beneficial biological measure of calcineurin inhibition than blood levels measurements for optimizing cyclosporine dosing [41,42]. On the other hand, the researches exhibited that there is a relationship between cyclosporine effect and its levels in the blood and the impairment of donor T-cell function by high blood concentrations may account for the effect of high concentrations of cyclosporine on engraftment [15]. Interestingly, recent investigations demonstrated that there is a good negative correlation between steady-state cyclosporine blood levels obtained at C2 and CD4 T-helper cell count [43]. Therefore, it can be concluded from the above-mentioned clinical pharmacokinetic studies $[15,41-43]$ that, though T-cell count gives a direct pharmacodynamic measure for the biological effect of cyclosporine in organ transplant patients, nevertheless, monitoring of cyclosporine blood concentrations particularly at C2 may be considered as the key and guide for optimal therapy of the drug.

The current investigation revealed that the common biochemical changes and adverse effects associated with cyclosporine therapy in Iraqi bone marrow transplant patients (Tables 5 and 6) were similar to that reported for Iraqi kidney transplant recipients [44,45]. Moreover, the primary biochemical changes and adverse effects of the drug reported in organ transplant patients of other nations were also identical to the present results such as electrolytes disturbances [46], hyperlipidemia [47], nephrotoxicity [48], cardiovascular risk [49], and elevation of blood pressure [50,51]. Unexpected biochemical changes and adverse effects of cyclosporine other than that found in literature and the current investigation were not registered.

\section{Conclusions}

The data obtained from adult Iraqi bone marrow transplant patients demonstrated that monitoring cyclosporine steady-state blood concentration at $\mathrm{C} 2$ and possibly $\mathrm{C} 3$ gave best correlations with $\mathrm{AUC}_{0-4 \mathrm{~h}}$ and $\mathrm{AUC}_{0-12 \mathrm{~h}}$ than all other concentrations obtained during the entire $12 \mathrm{~h}$ dosing interval particularly the trough concentrations $\mathrm{C} 0$ or $\mathrm{C} 12$ which exhibited poor correlations. The present findings are similar to those demonstrated in many nations and different types of organ transplantation. Therefore, for Iraqi bone marrow transplant patients, a single blood sample taken at $\mathrm{C} 2$ and possibly $\mathrm{C} 3$ can be utilized as a surrogate index for reflecting total drug exposure (AUC) and may be used in clinical practice since it represents the optimal blood sampling time for predicting the therapeutic and toxic effects of cyclosporine.

Author Contributions: Conceptualization, H.M.A. and J.J.I.; methodology, K.F.A.-T. and D.J.A.-T.; software, D.J.A.-T. and J.J.I.; validation, H.M.A., K.F.A.-T., D.J.A.-T. and J.J.I.; formal analysis, H.M.A., K.F.A.-T., D.J.A.-T. and J.J.I.; investigation, H.M.A., K.F.A.-T., D.J.A.-T. and J.J.I.; resources, H.M.A. and J.J.I.; data curation, K.F.A.-T., D.J.A.-T. and J.J.I.; writing-original draft preparation, D.J.A.-T. and J.J.I.; writing—review and editing, D.J.A.-T. and J.J.I.; visualization, H.M.A., K.F.A.-T., D.J.A.-T. and J.J.I.; supervision, H.M.A., K.F.A.-T., D.J.A.-T. and J.J.I.; 
project administration, H.M.A., K.F.A.-T., D.J.A.-T. and J.J.I. All authors have read and agreed to the published version of the manuscript.

Acknowledgments: The authors express sincere thanks and appreciation for all the patients who participated in the study. Besides, the authors would like to thank the staff who conducted the clinical and analytical parts of the study. Special acknowledgment to Mariam Al-Tamimi for the technical and language-proofing assistance in editing this article.

Conflicts of Interest: The authors declare no conflict of interest.

\section{References and Notes}

1. Neoral ${ }^{\circledR}$ Prescribing Information; Novartis Pharmaceuticals Corporation: East Hanover, NJ, USA, 2015.

2. Azzi, J.; Sayegh, M.; Mallat, S. Calcineurin Inhibitors: 40 Years Later, Can't Live Without. J. Immunol. 2013, 191, 5785-5791. [CrossRef] [PubMed]

3. Lindholm, A. Factors influencing the pharmacokinetics of cyclosporine in man. Ther. Drug Monit. 1991, 13, 465-477. [CrossRef] [PubMed]

4. Golubovic, B.; Prostran, M.; Miljkovic, B.; Vucicevic, K.; Radivojevic, D.; Grabnar, I. Population pharmacokinetic approach of immunosuppressive therapy in kidney transplant patients. Curr. Med. Chem. 2016, 23, 1998-2011. [CrossRef]

5. Xue, L.; Zhang, W.W.; Ding, X.L.; Zhang, J.J.; Bao, J.A.; Miao, L.Y. Population pharmacokinetics and individualized dosage prediction of cyclosporine in allogeneic hematopoietic stem cell transplant patients. Am. J. Med. Sci. 2014, 348, 448-454. [CrossRef] [PubMed]

6. Schiff, J.; Cole, E.; Cantarovich, M. Therapeutic monitoring of calcineurin inhibitors for the nephrologist. Clin. J. Am. Soc. Nephrol. 2007, 2, 374-384. [CrossRef]

7. Jacobson, P.A.; Ng, J.; Green, K.G.; Rogosheske, J.; Brundage, R. Post-transplant day significantly influences pharmacokinetics of cyclosporine after hematopoietic stem cell transplantation. Biol. Blood Marrow Transplant. 2003, 9, 304-311. [CrossRef]

8. Guidance for Industry, FDA. Bioavailability and Bioequivalence Studies for Orally Administered Drug Products. General Considerations; 2003.

9. Guidance for Industry, FDA. Bioequivalence Studies with Pharmacokinetic Endpoints for Drugs Submitted under an ANDA. Draft Guidance; 2013.

10. European Medicines Agency (EMEA). Guidelines on the Investigation of Bioequivalence; 2010.

11. Shargel, L.; Andrew, Y. Applied Biopharmaceutics and Pharmacokinetics, 6th ed.; McGraw-Hill Education: New York, NY, USA, 2012.

12. Malcolm, R.; Thomas, N.T. Clinical Pharmacokinetics and Pharmacodynamics: Concepts and Applications, 4th ed.; LWW: Philadelphia, PA, USA, 2011.

13. Sara, Z.; Molouk, H.; Asieh, A.; Amir, S.; Seyed, H.K.; Sara, M.; Mania, R.; Ardeshir, G. Assessment of cyclosporine serum concentrations on the incidence of acute graft versus host disease post-hematopoietic stem cell transplantation. Iran. J. Pharm. Res. 2014, 13, 305-312.

14. García, C.I.; Valcarcel, D.; Martino, R.; Piñana, J.L.; Barba, P.; Novelli, S.; Esquirol, A.; Garrido, A.; Saavedra, S.; Granell, M.; et al. Impact of Cyclosporine Levels on the Development of Acute Graft versus Host Disease after Reduced Intensity Conditioning Allogeneic Stem Cell Transplantation. Mediat. Inflamm. 2014, 2014, 620682.

15. Gerull, S.; Arber, C.; Bucher, C.; Gratwohl, A.; Halter, J.; Heim, D.; Tichelli, A.; Stern, M. Cyclosporine levels and rate of graft rejection following non-myeloablative conditioning for allogeneic hematopoietic SCT. Bone Marrow Transplant. 2010, 46, 740-746. [CrossRef]

16. Sibbald, C.; Seto, W.; Taylor, T.; Saunders, E.F.; Doyle, J.; Dupuis, L.L. Determination of area under the whole blood concentration versus time curve after first intravenous cyclosporine dose in children undergoing hematopoietic stem cell transplant: Limited sampling strategies. Ther. Drug Monit. 2008, 30, 434-438. [CrossRef]

17. Shibata, N.; Hoshino, N.; Minouchi, T.; Yamaji, A.; Park, K.; Tomoyoshi, T.; Abe, H.; Kodama, M. Relationship between area under the concentration versus time curve of cyclosporine $\mathrm{A}$, creatinine clearance, hematocrit value, and other clinical factors in Japanese renal transplant patients. Int. J. Clin. Pharmacol. Ther. 1998, 36, 202-209. [PubMed] 
18. Sarem, S.; Nekka, F.; Barrière, O.; Bittencourt, H.; Duval, M.; Teira, P.; Haddad, E.; Théorêt, Y.; Lapeyraque, A.L.; Litalien, C. Limited sampling strategies for estimating intravenous and oral cyclosporine area under the curve in pediatric hematopoietic stem cell transplantation. Ther. Drug Monit. 2015, 37, 198-205. [CrossRef] [PubMed]

19. Srinivas, N.R. Therapeutic drug monitoring of cyclosporine and area under the curve prediction using a single time point strategy: Appraisal using peak concentration data. Biopharm. Drug Dispos. 2015, 36, 575-586. [CrossRef] [PubMed]

20. Frassetto, L.A.; Tan-Tam, C.C.; Barin, B.; Browne, M.; Wolfe, A.R.; Stock, P.G.; Roland, M.; Benet, L.Z. Best single time point correlations with AUC for cyclosporine and tacrolimus in HIV-infected kidney and liver transplant recipients. Transplantation 2014, 97, 702-707. [CrossRef] [PubMed]

21. Yixin, J.I.A.; Xu, M.; Yan, L.; Chunlei, X.U.; Wen, Z.; Yuqing, J.; WEI, H. Optimal sampling time-point for cyclosporine A concentration monitoring in heart transplant recipients. Exp. Ther. Med. 2018, 16, 4265-4270.

22. Jaksch, P.; Kocher, A.; Neuhauser, P.; Sarahrudi, K.; Seweryn, J.; Wisser, W.; Klepetko, W. Monitoring C2 level predicts exposure in maintenance lung transplant patients receiving the microemulsion formulation of cyclosporine (Neoral). J. Heart Lung Transplant. 2005, 24, 1076-1080. [CrossRef]

23. Morris, R.G. Cyclosporin therapeutic drug monitoring -an established service revisited. Clin. Biochem. Rev. 2003, 24, 33-46.

24. Cantarovich, M.; Barkun, J.S.; Tchervenkov, J.I.; Besner, J.G.; Aspeslet, L.; Metrakos, P. Comparison of neoral dose monitoring with cyclosporine through levels versus 2-hr postdose levels in stable liver transplant patients. Transplantation 1998, 66, 1621-1627. [CrossRef]

25. Cantarovich, M.; Besner, J.G.; Barkun, J.S.; Elstein, E.; Loertscher, R. Two-hour cyclosporine level determination is the appropriate tool to monitor Neoral therapy. Clin. Transplant. 1998, 12, 243-249.

26. Kong, D.C.M.; Shuttleworth, P.; Bailey, M.; Grigg, A. CsA 2-h concentration correlates best with area under the concentration-time curve after allo-SCT compared with trough CsA. Bone Marrow Transplant. 2012, 47, 54-59. [CrossRef]

27. Henriques, L.S.; Matos, F.M.; Vaisbich, M.H. Pharmacokinetics of cyclosporin-A microemulsion in children with idiopathic nephrotic syndrome. Clinics 2012, 67, 1197-1202. [CrossRef]

28. Jorga, A.; Holt, D.W.; Johnston, A. Therapeutic drug monitoring of cyclosporine. Transplant. Proc. 2004, 36 (Suppl. 2), S396-S403. [CrossRef] [PubMed]

29. Wada, Y.; Kotani, T.; Takeuchi, T.; Wakura, R.; Wakura, D.; Makino, S.; Hanafusa, T. Therapeutic drug monitoring of cyclosporine microemulsion in patients with corticosteroid-resistant systemic lupus erythematosus. Mod. Rheumatol. 2015, 25, 708-713. [CrossRef] [PubMed]

30. Furukawa, T.; Kurasaki-Ida, T.; Masuko, M.; Tsukada, N.; Okazuka, K.; Sato, N.; Yano, T.; Abe, T.; Momoi, A.; Shibasaki, Y.; et al. Pharmacokinetic and pharmacodynamic analysis of cyclosporine A (CsA) to find the best single time point for the monitoring and adjusting of CsA dose using twice-daily 3-h intravenous infusions in allogeneic hematopoietic stem cell transplantation. Int. J. Hematol. 2010, 92, 144-151. [CrossRef] [PubMed]

31. Duncan, N.; Arrazi, J.; Nagra, S.; Cook, M.; Thomson, A.H.; Craddock, C. Prediction of intravenous cyclosporine area under the concentration-time curve after allogeneicstem cell transplantation. Ther. Drug Monit. 2010, 32, 353-358. [CrossRef] [PubMed]

32. Eljebari, H.; Ben, F.N.; Salouage, I.; Gaies, E.; Trabelsi, S.; Jebabli, N.; Lakhal, M.; Ben Othman, T.; Kouz, A. Estimation of abbreviated cyclosporine A area under the concentration-time curve in allogenic stem cell transplantation after oral administration. J. Transplant. 2012, 2012, 342701. [CrossRef] [PubMed]

33. Dupuis, L.L.; Seto, W.; Teuffel, O.; Gibson, P.; Schultz, K.R.; Doyle, J.D.; Gassas, A.; Egeler, R.M.; Sung, L.; Schechter, T. Prediction of area under the cyclosporine concentration versus time curve in children undergoing hematopoietic stem cell transplantation. Biol. Blood Marrow Transplant. 2013, 19, 418-423. [CrossRef]

34. Schrauder, A.; Saleh, S.; Sykora, K.W.; Hoy, H.; Welte, K.; Boos, J.; Hempel, G.; Grigull, L. Pharmacokinetic monitoring of intravenous cyclosporine A in pediatric stem-cell transplant recipients. The trough level is not enough. Pediatr. Transplant. 2009, 13, 444-450. [CrossRef]

35. Nashan, B.; Cole, E.; Levy, G.; Thervet, E. Clinical validation studies of neoral C2 monitoring: A review. Transplantation 2002, 73 (Suppl. 9), S3-S11. [CrossRef]

36. Pescovitz, M.D.; Barbeito, R. Two-hour post-dose cyclosporine level is a better predictor than trough level of acute rejection of renal allografts. Clin. Transplant. 2002, 16, 378-382. [CrossRef] 
37. Duncan, N.; Craddock, C. Optimizing the use of cyclosporine in allogeneic stem cell transplantation. Bone Marrow Transplant. 2006, 38, 169-174. [CrossRef] [PubMed]

38. Levy, G.; Thervet, E.; Lake, J.; Uchida, K. Patient management by Neoral C(2) monitoring: An international consensus statement. Transplantation 2002, 73 (Suppl. 9), S8-S12. [CrossRef] [PubMed]

39. ICH Guideline for Good Clinical Practice (GCP), E6; 1996.

40. Latest WMA Declaration of Helsinki. Ethical Principles for Medical Research Involving Human Subjects; 2013.

41. Sanquer, S.; Schwarzinger, M.; Maury, S.; Yakouben, K.; Rafi, H.; Pautas, C.; Kuentz, M.; Barouki, R.; Cordonnier, C. Calcineurin activity as a functional index of immunosuppression after allogeneic stem-cell transplantation. Transplantation 2004, 77, 854-858. [CrossRef] [PubMed]

42. Sommerer, C.; Giese, T.; Schmidt, J.; Meuer, S.; Zeier, M. Ciclosporin A tapering monitored by NFAT-regulated gene expression: A new concept of individual immunosuppression. Transplantation 2008, 85, 15-21. [CrossRef]

43. Al-Tamimi, J.J.; Al-Khames, Q.A.; Abass, H.M. CD4 T-Helper cell count is as an alternative promising marker for dosing cyclosporine in kidney transplant patient. IJPPS 2016, 8, 85-92.

44. Al-Khames, Q.A.; Al-Tamimi, J.J.; Abass, H.M.; Alawi, A.A.; Al-Tamimi, K.F. Adverse effects and biochemical changes, in Iraqis kidney transplanted patients using cyclosporine. Pharm. Glob. 2015, 1, 1-11.

45. Al-Temimi, H.M.; Ghareeb, M.M.; Dyab, A.A.; Al-Tamimi, K.F. Therapeutic monitoring of cyclosporine-A in Iraqi patients kidney transplanted. WJPP 2014, 10, 50-59.

46. Einollahi, B.; Nemati, E.; Rostami, Z.; Teimoori, M.; Ghadian, A.R. Electrolytes disturbance and cyclosporine blood levels among kidney transplant recipients. Int. J. Org. Transplant. Med. 2012, 3, 166-175.

47. Chavers, B.M.; Hårdstedt, M.; Gillingham, K.J. Hyperlipidemia in pediatric kidney transplant recipients treated with cyclosporine. Pediatr Nephrol. 2003, 18, 565-569. [CrossRef]

48. Morales, J.M.; Wramner, L.; Kreis, H.; Durand, D.; Campistol, J.M.; Andres, A.; Arenas, J.; Nègre, E.; Burke, J.T.; Growth, C.G. Sirolimus does not exhibit nephrotoxicity compared to cyclosporine in renal transplant recipients. Am. J. Transplant. 2002, 2, 436-442. [CrossRef]

49. Lucey, M.R.; Abdelmalek, M.F.; Gagliardi, R.; Granger, D.; Holt, C.; Kam, I.; Klintmalm, G.; Langnas, A.; Shetty, K.; Tzakis, A.; et al. A comparison of tacrolimus and cyclosporine in liver transplantation: Effects on renal function and cardiovascular risk status. Am. J. Transplant. 2005, 5, 1111-1119. [CrossRef] [PubMed]

50. Marienhagen, K.; Lehner, F.; Klempnauer, J.; Hecker, H.; Borlak, J. Treatment of cyclosporine induced hypertension: Results from long-term observational study using different antihypertensive medications. Vascul. Pharmacol. 2019, 115, 69-83. [CrossRef] [PubMed]

51. Robert, N.; Wong, G.W.; Wright, J.M. Effect of cyclosporine on blood pressure. Cochrane Database Syst. Rev. 2010, CD007893. [CrossRef] [PubMed]

(C) 2020 by the authors. Licensee MDPI, Basel, Switzerland. This article is an open access article distributed under the terms and conditions of the Creative Commons Attribution (CC BY) license (http://creativecommons.org/licenses/by/4.0/). 